\title{
RELATIVE GROWTH OF Petrochirus diogenes (LINNAEUS, 1758) (CRUSTACEA, ANOMURA, DIOGENIDAE) IN THE UBATUBA REGION, SÃO PAULO, BRAZIL
}

\author{
BERTINI, G. and FRANSOZO, A. \\ NEBECC (Group of Studies on Crustacean Biology, Ecology and Culture), Departamento de Zoologia, Instituto de \\ Biociências, Universidade Estadual Paulista, UNESP, CEP 18618-000, Botucatu, SP, Brazil \\ Correspondence to: Adilson Fransozo, NEBECC (Group of Studies on Crustacean Biology, Ecology and Culture), \\ Departamento de Zoologia, Instituto de Biociências, Universidade Estadual Paulista, UNESP, CEP 18618-000, \\ Botucatu, SP, Brazil, e-mail: fransozo@ibb.unesp.br \\ Received September 9, 1998 - Accepted November 26, 1998 - Distributed December 22, 1999
}

(With 7 figures)

\begin{abstract}
The purpose of this paper is to investigate the relative growth and heterochely in the hermit crab Petrochirus diogenes. Hermit crabs were collected in the Ubatuba region, SP, from 1993 to 1996; using a commercial fishing boat equipped with two double-rig nets. Body mass of each individual was weighed and their cephalothoracic shield and chelar propodus size were measured. Body mass and chelar propodus size were regarded as dependent variables and plotted against length of cephalothoracic shield according to the allometric equation $\mathrm{y}=\mathrm{a} \cdot \mathrm{x}^{\mathrm{b}}$. A total of 479 individuals were obtained being 307 males and 172 females. Cephalothoracic shield width follows an isometric growth for both sexes. Otherwise, right cheliped dimensions show different relative growth patterns and left cheliped ones present a positive allometry in males and females. Unlike brachyurans, ontogenetic changes in the growth rate of chelar propodus are not clearly discernible, which prevents the accurate detection of allometric variations. In both sexes, the right cheliped is larger than the right one. Cheliped size is a sexual dimorphic feature with males bearing larger chelipeds than females. Heterochely may be particularly adaptive in agonistic interactions and precopulatory behaviour in $P$. diogenes.
\end{abstract}

Key words: relative growth, hermit crab, Petrochirus, Diogenidae.

\section{RESUMO}

\section{Crescimento relativo de Petrochirus diogenes}

O presente trabalho tem por objetivo investigar o crescimento relativo e a heteroquelia de Petrochirus diogenes. Os indivíduos foram coletados com um barco de pesca comercial, equipado com duas redes do tipo "double-rig", durante o período de 1993 a 1996, na região de Ubatuba, SP. Os indivíduos foram pesados e mensurados na região do escudo cefalotorácico e dos própodos quelares. Os dados foram plotados em função do comprimento do escudo e ajustados na equação $\mathrm{y}=\mathrm{a} \cdot \mathrm{x}^{\mathrm{b}}$. Foram obtidos 479 exemplares (307 machos e 172 fêmeas). Nas relações do escudo, obteve-se um crescimento isométrico para ambos os sexos. As relações do quelípodo direito mostraram diferentes padrões de crescimento, enquanto o esquerdo apresentou uma alometria positiva para ambos os sexos. Para os ermitões, as mudanças em relação as partes ou apêndices não são tão visíveis como nos braquiúros, impossibilitando a detecção das alterações alométricas com precisão. Na análise da heteroquelia, observou-se que $P$. diogenes apresenta o quelípodo direito maior em ambos os sexos, no entanto, os machos atingem tamanhos superiores. A presença de heteroquelia pode beneficiar o ermitão durante as interações agonísticas e nos comportamentos pré-copulatórios.

Palavras-chave: crescimento relativo, ermitão, Petrochirus, Diogenidae. 


\section{INTRODUCTION}

Scientific contributions concerning relative growth in crustaceans can supplement the community's understanding in restricted areas (Donaldson et al., 1981), evaluate the stages of crustacean development (Haley, 1973) or even aid in the identification of species (Clayton, 1990).

Growth in hermit crabs has mainly focused its relation with shell. The first author to suggest that gastropod shells constrain growth in hermit crabs was Drapkin (1963), after observing that populations of Clibanarius misanthropus and Diogenes varians in the Black Sea were known only as dwarf races before the introduction of the gastropod genus Rapana. Other authors tested in laboratory the influence of gastropod shells in hermit crabs growth, for which we can highlight the work accomplished by Markham (1968), Fotheringham (1976a, b), Bertness (1981a, b) and Blackstone (1985).

Some research on relative growth in hermit crabs did not establish relationships with shell size, as in the studies by Emmerson \& Alexander (1986) for Diogenes brevirostris; Gherardi (1991) for Clibanarius erythropus; Gherardi \& Maclaughlin (1994) for Clibanarius humilis and Clibanarius striolatus; Gherardi \& Cassidi (1995) for Discorsopagurus schmitti; and Manjón-Cabeza \& García-Raso (1995), for Calcinus tubularis.

Heterochely is the presence of differences in form, size and function between chelae of opposite sides, which has varying intensities in different species (Hartnoll, 1982). The phenomenon of heterochely is found in many decapod families, e.g. Xanthidae, Gecarcinidae and Alpheidae. In the case of hermit crabs, heterochely can be shaped according to the form of the host shell opening. Blackstone (1986) observed that in populations of Pagurus longicarpus occupying shells of inadequate sizes, the chelipeds exhibited high allometric rates, to the point that individuals in appropriately sized shells had considerably decreased allometry.

The objective of this paper is to establish allometric relationships that best characterize the relative growth of Petrochirus diogenes and verify if there are any significant changes related to sexual maturity. The occurrence of heterochely in both sexes is also reported.

\section{MATERIAL AND METHODS}

Monthly collections from 1993 to 1996 were carried out with the aid of a commercial fishing boat equipped with two double-rig drag nets, at a location in the north coast of São Paulo State between the latitudes $23^{\circ} 20^{\prime}-23^{\circ} 35^{\prime} \mathrm{S}$ and longitudes $44^{\circ} 50^{\prime}-45^{\circ} 14^{\prime} \mathrm{W}$.

The shells of the crabs were removed using a vise or manually when it was possible. All individuals were sexed after examination of genital openings, as the gonopores are evident at the base of the coxa of the third pair of pereiopods in females and in the base of the fifth in males.

The dimensions chosen for morphometric analyses were the following: cephalothoracic shield length (SL) and width (SW), left chelar propodus length (LPL) and height (LPH) and right chelar propodus length (RPL) and height (RPH) (Fig. 1). Measurements were taken with the aid of a caliper. Wet weight of total body mass and wet weight of chelipeds were also recorded with a precision of $0.1 \mathrm{~g}$. Length of the cephalothoracic shield, considered by Markham (1968) and Blackstone (1986) as the best measure for hermit crabs size, was regarded as the independent variable. All remaining dimensions were plotted against SL, and the allometric equation $\mathrm{Y}=\mathrm{a} \cdot \mathrm{X}^{\mathrm{b}}$ was fitted to these relationships using the least-squares regression method.

Departures from isometry $\left(\mathrm{H}_{\mathrm{o}}: \mathrm{b}=1\right)$ were tested using a student's t-test on the obtained slope values. 95\% confidence intervals for size of right and left chelipeds were calculated for heterochely analyses.

Student t-tests were also performed to verify if slopes and intercepts of obtained straight lines differ within each allometric relationship.

\section{RESULTS}

A total of 479 individuals were obtained, being 307 males and 172 females. Shield length of males varied from 5.4 to $40.0 \mathrm{~mm}$, with a mean size of $17.7 \pm 6.7 \mathrm{~mm}$.

In females, size varied from 5.7 to $32.1 \mathrm{~mm}$, with an average of $14.7 \pm 4.9 \mathrm{~mm}$.

A single regression equation was obtained for males because changes in the relative growth of chelae were not detected. 


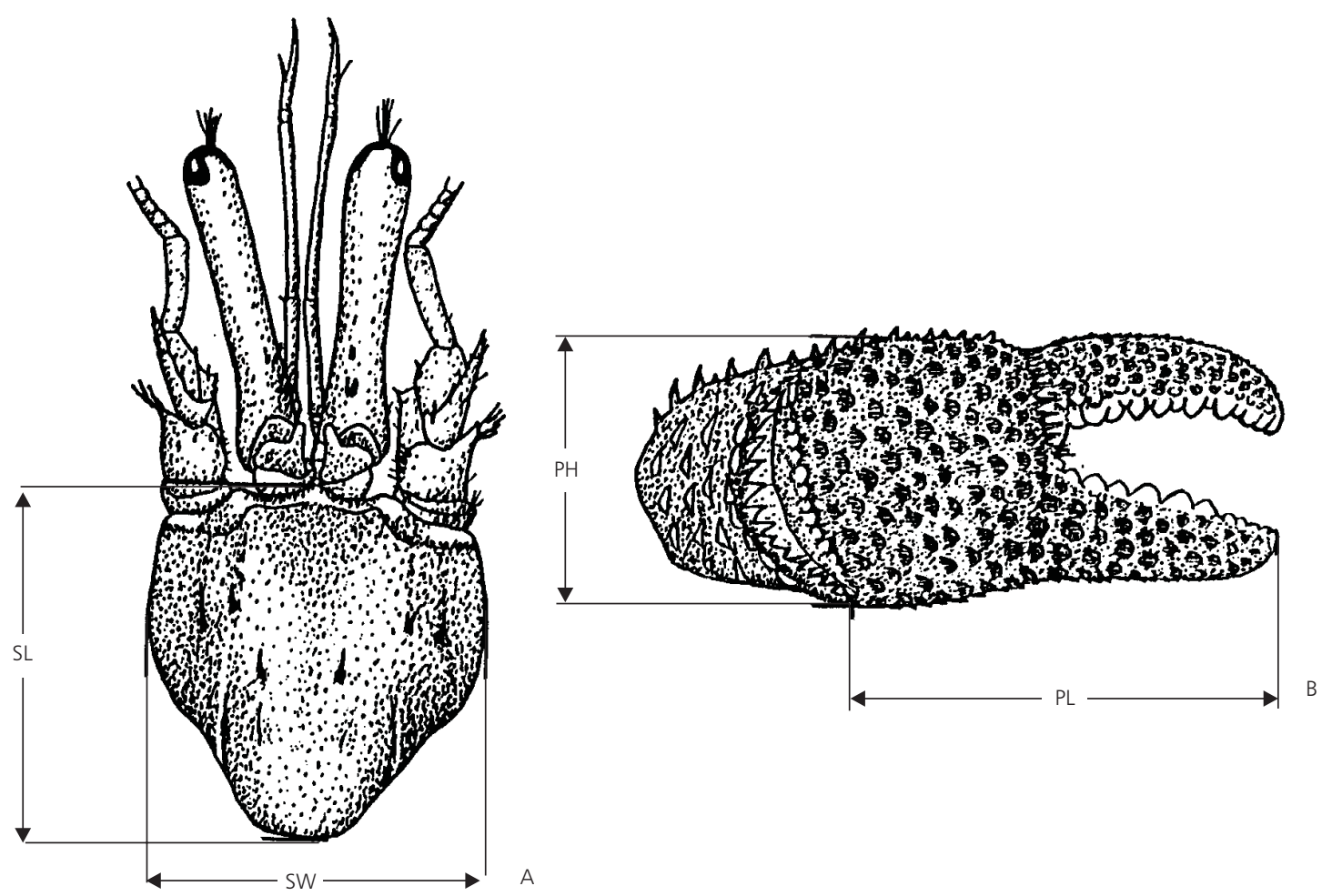

Fig. 1 - Petrochirus diogenes. Position of the measured morphometric variables. A) cephalothoracic shield length (SL); cephalothoracic shield width (SW). B) chelar propodus height (PH); chelar propodus length (PL).

In females, the separation of juvenile and adult individuals was based on the size of smallest ovigerous female $(\mathrm{SL}=10.0 \mathrm{~mm})$. Females smaller than this size were considered immature.

Table 1 shows the regression equations obtained in the relative growth analyses. The SW $\mathrm{x}$ SL regression plotted to all individuals indicates an isometric relationship between these variables. Intercepts and slopes of a given allometric relationship do not differ between males and females. Therefore, single regression lines both sexes can be obtained instead (Fig. 2).

Otherwise, regression parameters of all allometric relationships involving chelar propodus in juvenile and adult females are statistically different ( $p<0.05)$, except for LPL x SL.

Height and length of the right chelar propodus exhibit a higher allometric level in juvenile females. In females a positive allometric growth was verified in all relationships obtained for the left cheliped (Table 1, Fig. 3). As observed in males, a slight inflection can be noticed in both height and length of left chelar propodus relationships, at about 25 mm SL (Fig. 4).

A clear heterochely, with larger right chelae, was observed in each sex. Aside from this, it can also be noticed that males bear larger right and left chelipeds than females (Fig. 5).

Comparisons of average total weight and mean weight of chelipeds are shown in Fig. 6. Both total weight and chelipeds weight are significantly different between sexes $(p<0.05)$.

\section{DISCUSSION}

The isometric growth observed for the relationship SW x SL in $P$. diogenes was also observed in Clibanarius erythropus by Gherardi (1991) and for Calcinus tubularis for ManjónCabeza \& García-Raso (1995). Unlike this, other organs are known to undergo significant variations in their growth rate and even in their morphology. 
TABLE 1

Petrochirus diogenes. Regression analyses. SL: shield length; SW: shield width; RPH: right propodus height; RPL: right propodus length; LPH: left propodus height; LPL: left propodus length; T: total; J: juvenile; A: adults; N: number of individuals; In: natural logarithm; AL: allometric level.

\begin{tabular}{|c|c|c|c|c|c|c|c|}
\hline Variables & Group & $\mathbf{N}$ & $\begin{array}{l}\text { Equation } \\
\mathbf{y}=\mathbf{a} \cdot \mathbf{x}^{\mathbf{b}}\end{array}$ & $\begin{array}{l}\text { Linear Transformation } \\
\qquad \ln y=\ln a+b \cdot \ln x\end{array}$ & $\mathbf{r}^{2}$ & $\mathbf{A L}$ & $\mathbf{b} \neq \mathbf{1}$ \\
\hline \multirow[t]{5}{*}{ SW } & Males(T) & 307 & $\mathrm{SW}=0.939 . \mathrm{SL}^{1.01}$ & $\ln \mathrm{SW}=-0.063+1.01 \ln \mathrm{SL}$ & 0.99 & $=$ & $0.0014^{\mathrm{ns}}$ \\
\hline & Females(T) & 172 & $\mathrm{SW}=0.976 . \mathrm{SL}^{0.99}$ & $\ln \mathrm{SW}=-0.024+0.99 \operatorname{lnSL}$ & 0.98 & $=$ & $0.001^{\mathrm{ns}}$ \\
\hline & Total & 479 & $\mathrm{SW}=0.950 . \mathrm{SL}^{1.00}$ & $\mathrm{Ln} S W=-0.051+1.00 \operatorname{lnSL}$ & 0.99 & $=$ & $0.001^{\mathrm{ns}}$ \\
\hline & Males(T) & 307 & $\mathrm{RPH}=1.06 . \mathrm{SL}^{1.04}$ & $\ln \mathrm{RPH}=0.058+1.04 \operatorname{lnSL}$ & 0.95 & + & $2.96^{*}$ \\
\hline & Females(T) & 172 & $\mathrm{RPH}=0.914 \mathrm{SL}^{1.10}$ & $\ln \mathrm{RPH}=-0.090+1.10 \ln \mathrm{SL}$ & 0.92 & + & $3.46^{*}$ \\
\hline \multirow[t]{3}{*}{ RPH } & Females $(J)$ & 30 & $\mathrm{RPH}=0.62 . \mathrm{SL}^{1.27}$ & $\ln \mathrm{RPH}=-0.478+1.27 \operatorname{lnSL}$ & 0.81 & + & $2.34^{*}$ \\
\hline & Females(A) & 142 & $\mathrm{RPH}=1.09 . \mathrm{SL}^{1.03}$ & $\ln \mathrm{RPH}=0.083+1.03 \ln \mathrm{SL}$ & 0.87 & $=$ & $0.535^{\mathrm{ns}}$ \\
\hline & Males(T) & 307 & $\mathrm{RPL}=1.64 . \mathrm{SL}^{1.07}$ & $\ln \mathrm{RPL}=0.497+1.07 \ln \mathrm{SL}$ & 0.95 & + & $5.18 *$ \\
\hline \multirow[t]{4}{*}{ RPL } & Females(T) & 172 & $\mathrm{RPL}=1.83 . \mathrm{SL}^{1.02}$ & $\ln \mathrm{RPL}=0.603+1.02 \ln \mathrm{SL}$ & 0.92 & $=$ & $1.19^{\mathrm{ns}}$ \\
\hline & Females(J) & 30 & $\mathrm{RPL}=1.16 . \mathrm{SL}^{1.23}$ & $\ln \mathrm{RPL}=0.145+1.23 \ln \mathrm{SL}$ & 0.84 & + & $2.25^{*}$ \\
\hline & Females(A) & 142 & $\mathrm{RPL}=2.08 . \mathrm{SL}^{0.98}$ & $\ln \mathrm{RPL}=0.732+0.98 \ln \mathrm{SL}$ & 0.87 & $=$ & $0.135^{\mathrm{ns}}$ \\
\hline & $\operatorname{Males}(\mathrm{T})$ & 307 & $\mathrm{LPH}=0.723 . \mathrm{SL}^{1.12}$ & $\ln \mathrm{LPH}=-0.324+1.12 \operatorname{lnSL}$ & 0.96 & + & $9.23 *$ \\
\hline \multirow[t]{4}{*}{ LPH } & Females(T) & 172 & $\mathrm{LPH}=0.601 . \mathrm{SL}^{1.20}$ & $\ln \mathrm{LPH}=-0.509+1.20 \ln \mathrm{SL}$ & 0.95 & + & $8.26^{*}$ \\
\hline & Females(J) & 30 & $\mathrm{LPH}=0.520 . \mathrm{SL}^{1.26}$ & $\ln \mathrm{LPH}=-0.654+1.26 \ln \mathrm{SL}$ & 0.88 & + & $2.95^{*}$ \\
\hline & Females(A) & 142 & $\mathrm{LPH}=0.666 . \mathrm{SL}^{1.16}$ & $\ln \mathrm{LPH}=-0.407+1.16 \ln \mathrm{SL}$ & 0.91 & + & $4.09 *$ \\
\hline & Males(T) & 307 & $\mathrm{LPL}=1.10 . \mathrm{SL}^{1.16}$ & $\ln \mathrm{LPL}=0.095+1.16 \ln \mathrm{SL}$ & 0.97 & + & $13.22 *$ \\
\hline \multirow[t]{3}{*}{ LPL } & Females(T) & 172 & $\mathrm{LPL}=1.31 . \mathrm{SL}^{1.09}$ & $\ln \mathrm{LPL}=0.273+1.09 \ln \mathrm{SL}$ & 0.93 & + & $3.83 *$ \\
\hline & Females(J) & 30 & $\mathrm{LPL}=1.03 . \mathrm{SL}^{1.20}$ & $\ln \mathrm{LPL}=0.034+1.20 \ln \mathrm{SL}$ & 0.89 & + & $2.47 *$ \\
\hline & Females(A) & 142 & $\mathrm{LPL}=1.35 . \mathrm{SL}^{1.08}$ & $\ln \mathrm{LPL}=0.298+1.08 \ln \mathrm{SL}$ & 0.87 & + & $2.24 *$ \\
\hline
\end{tabular}

$* \mathrm{p}<0.05$

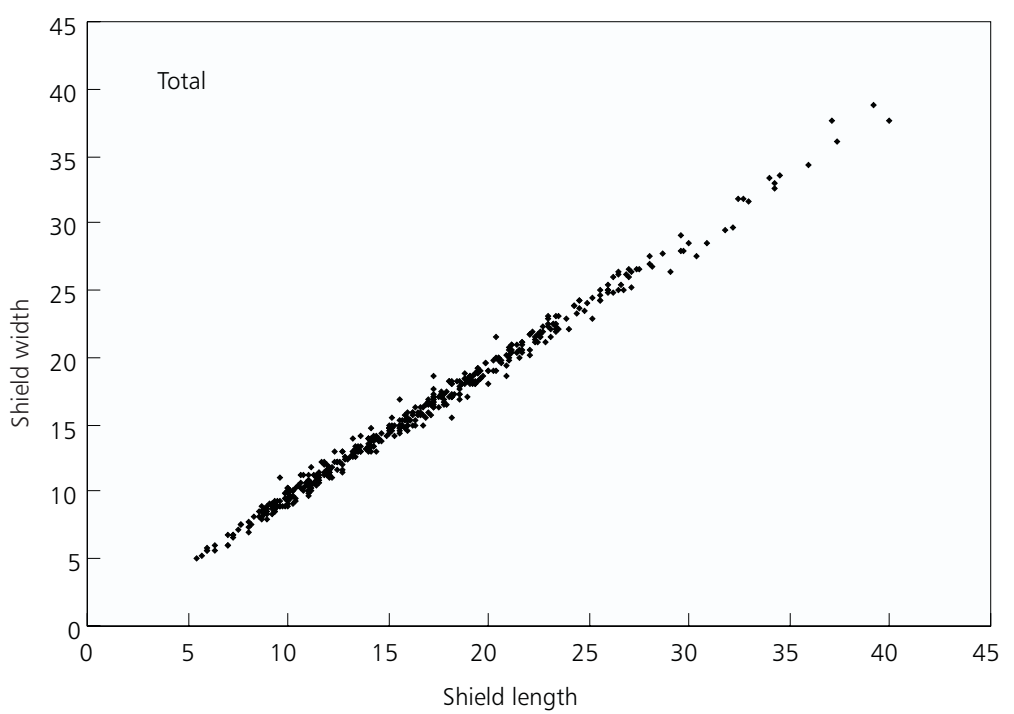

Fig. 2 - Petrochirus diogenes. Scatter plot between the length and width of cephalothoracic shield for all individuals. 


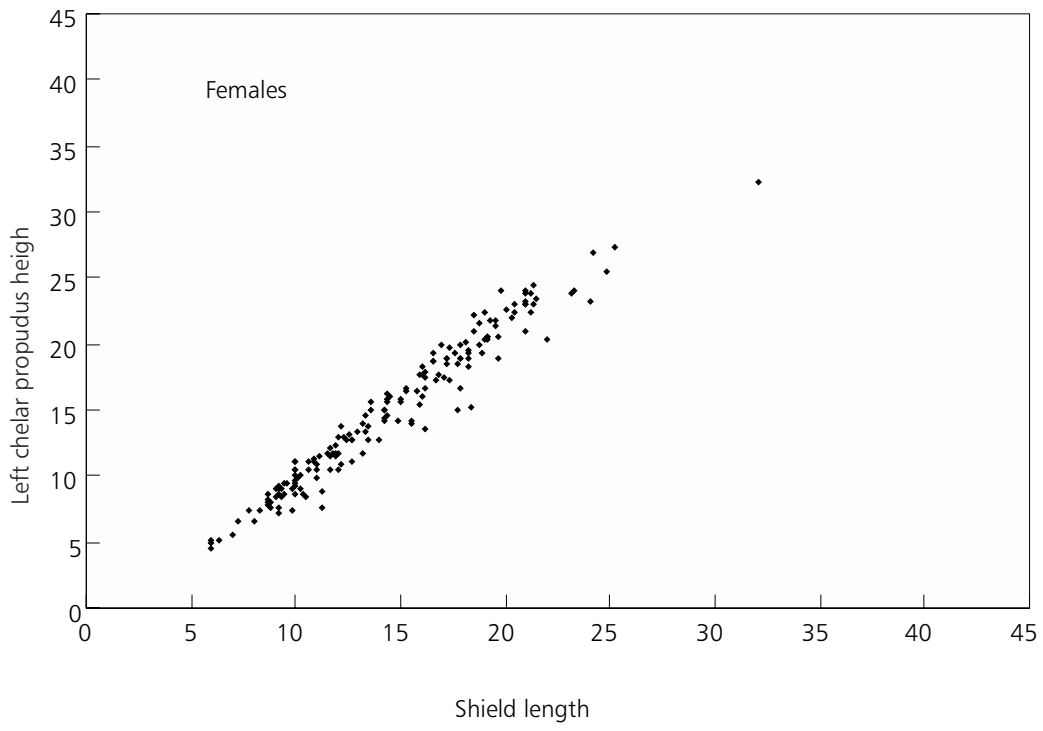

Fig. 3 - Petrochirus diogenes. Scatter plot between cephalothoracic shield length and chelar propodus in females.

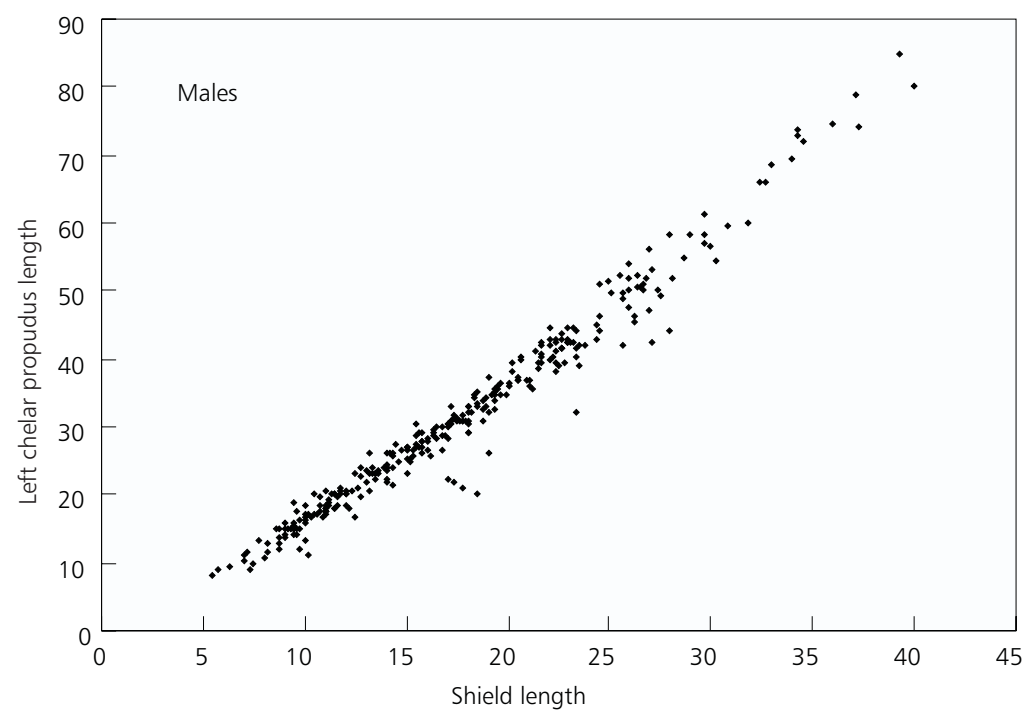

Fig. 4 - Petrochirus diogenes. Scatter plot between cephalothoracic shield length and chelar propodus length in males. 


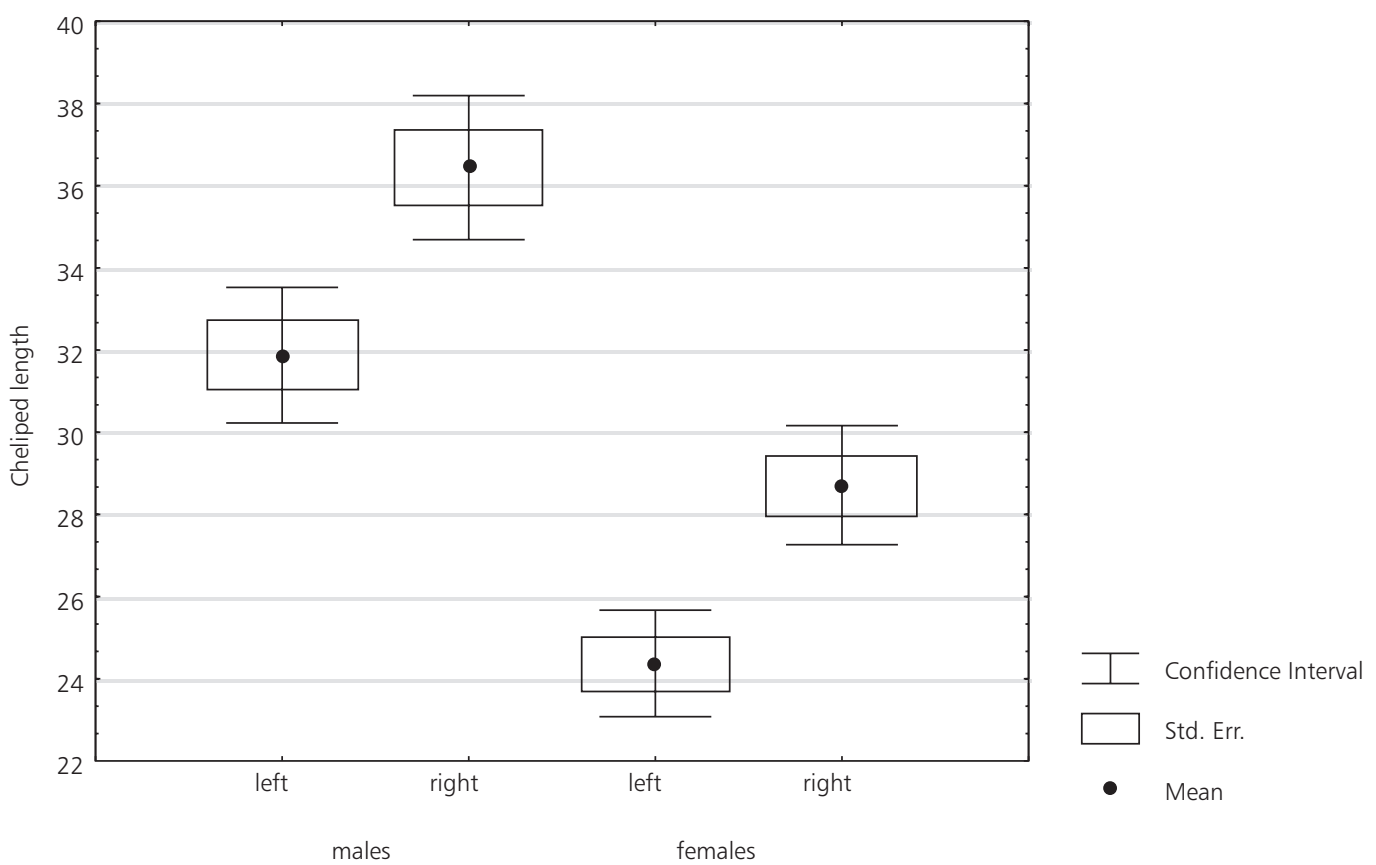

Fig. 5 - Petrochirus diogenes. Box plots of the length of right and left chelar propodus for both sexes.

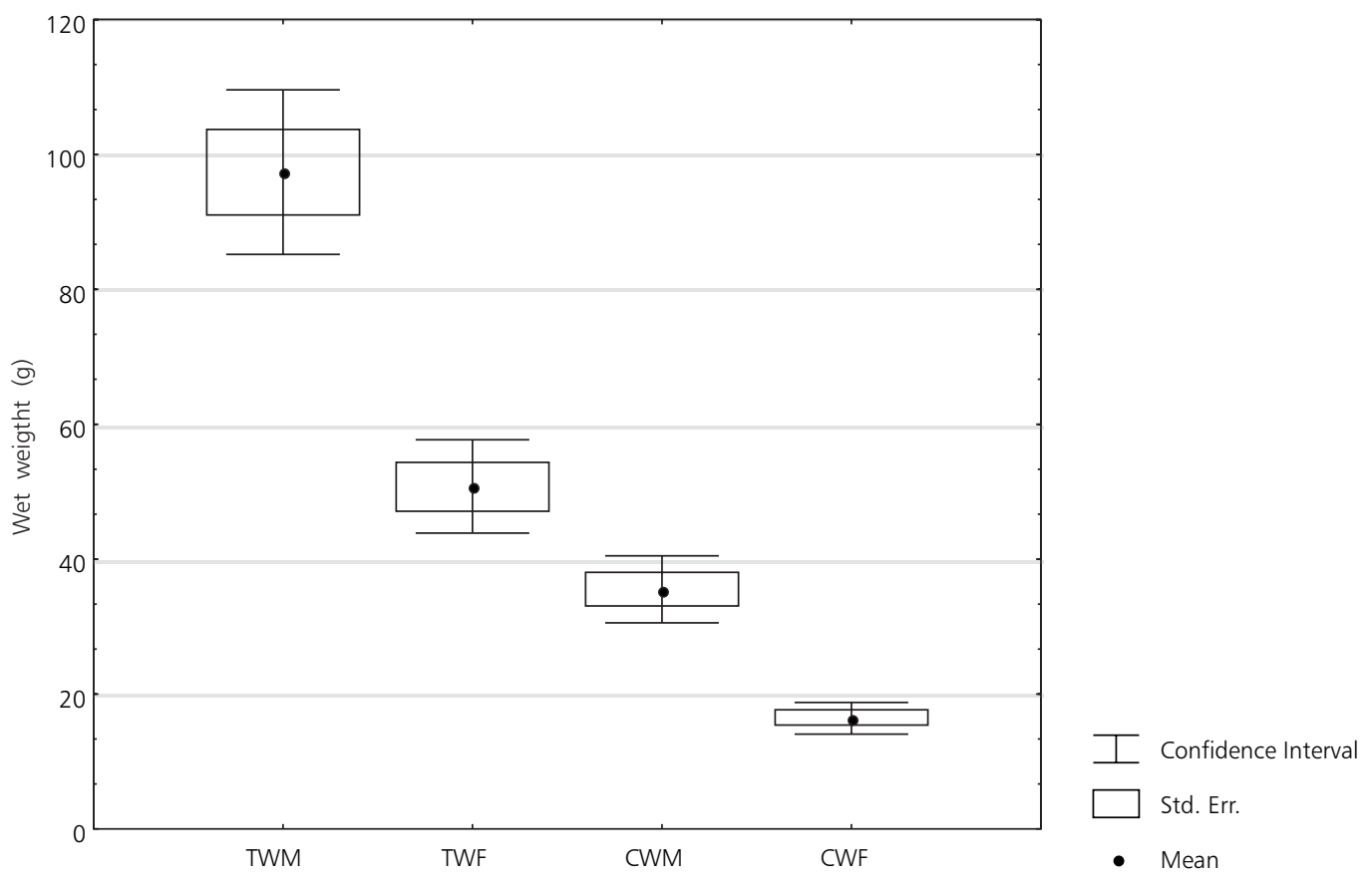

Fig. 6 - Petrochirus diogenes. Box plots of total wet weight and chelipeds weight for both sexes. TWM: total weight males; TWF: total weight females; CWM: chelar weight males; CWF: chelar weight females. 
In hermit crabs these changes are not as clear as in brachyurans. In $P$. diogenes, eventual allometric alterations during its development are not sufficiently clear as to allow their accurate detection in allometric analyses. Seemingly, such allometric changes were also absent in other results concerning relative growth in hermit crabs (Gherardi, 1991; ManjónCabeza \& García-Raso, 1995; Gherardi \& Cassidi, 1995). As a consequence, a single allometric model for all individuals was fitted in these studies.

In females, the separation of juveniles and adults based on smallest ovigerous female size (LS $-10 \mathrm{~mm}$ ) indicates that sexual maturity is taking place in crabs within the third size class (10-12.5 mm) (Bertini \& Fransozo, in press). This criterion was also adopted in three species of the genus Pagurus by Carlon \& Ebersole (1995) and Diogenes nitidimanus by Asakura (1995). According to Pinheiro \& Fransozo (1998), accurate size at sexual maturity estimates should include allometric studies of secondary sexual characters and micro- or macroscopic gonad examination since these values are often different.

The females of $P$. diogenes presented different growth patterns but, in the juvenile phase, a positive allometry was verified for all performed regressions. In relative growth analyses performed in other hermit crab species, allometric relationships were drawn without separating young and adult individuals, hindering therefore a comparison of results.

A differential growth was observed by Bertness (1981c), who verified that males often grow faster than females because they allocate a larger portion of energy towards growth. According to Bertini \& Fransozo (in press) $P$. diogenes males reach a larger size than females, suggesting that adult females would preferentially allocate energy towards egg production.

Heterochely is a characteristic feature of $P$. diogenes, in which both sexes present a larger chela. Cheliped size is also a sexual dimorphic characteristic, with males presenting larger claws than females. These results agree with previous descriptions accomplished by Forest \& Saint Laurent (1967), who mentioned that hermit crabs of the family Diogenidae usually bear chelipeds of same or unequal size with a larger left chela, except for the genus Petrochirus.

Provenzano (1968), who described the larval stages of $P$. diogenes, mentioned that heterochely with larger right cheliped is a characteristic already apparent in the megalopa, allowing an early identification of the genus.

In relation to the weight of chelipeds and total somatic weight, it was observed that males' weight is proportionately higher than females' weight. This difference is probably related to genetic characteristics and indicates a sexual dimorphism, which is also observed in other decapods such as Diogenes brevirostris studied by Emmerson \& Alexander (1986) and Hepatus pudibundus studied by Mantelatto \& Fransozo (1992) and Reigada et al. (1994).

In relative growth analyses, it was verified that male chelipeds undergo a positive allometric growth during their development, which is more pronounced in the left cheliped. In the allometric relationship LPL $x$ SL a positive allometric growth with a visible inflection occurring at $25 \mathrm{~mm} \mathrm{SL}$ was observed. As a result, the size difference between chelipeds is accentuated up to this size and, from that point, the relative left cheliped length begins to increase, thus decreasing the heterochely. For females, a similar trend occurs, however, it is more related with the height of chelar propodus.

The functional meaning of this sexual difference has been cited for brachyurans by Hartnoll (1974), in which the chelae are related with territorial defense, combat, exhibition, and courtship in males. The chelipeds are extensively used in fights for the ownership of larger or more appropriate shells and in aggressive interactions (Hazlett, 1966). In these situations, the hermit crab lifts the whole body and the shell, moving the larger cheliped forward until the dactylus is approximately perpendicular to the substratum. Such movement may incite agonistic behaviour in another hermit crab (Hazlett \& Bossert, 1965; Hazlett, 1966).

In this way, hermit crab individuals with larger chelipeds may have more success during intraspecific fights for mating, fighting and also in confrontations for more appropriate shells. Moreover, large chelipeds can be used for defense against predators, which may enhance survivorship.

Growth rates of individuals may be limited or even suppressed if there is no supply of adequate shells. Therefore, relative growth analyses can provide a basis for experimental studies addressing questions about the influence of shells in hermit crabs size. Using related literature and the results 
obtained in this study, it is possible to construct a fluxogram representing a more general analysis of relative growth in $P$. diogenes (Fig 7).

The study of the relative growth in pagurids has still not made great advances as in brachyuran crabs. Interesting allometric relationships would be different that those usually performed in brachyuran crabs. Therefore there is a need of standardizing the relationships examined, in order to enable future comparisons.

Acknowledgments - We are grateful to the Fundação de Amparo à Pesquisa do Estado de São Paulo (FAPESP) and Conselho Nacional de Desenvolvimento Científico e Tecnológico (CNPq). We are also thankful to the NEBECC co-workers for their help during collection and to Dra. Maria Lucia Negreiros Fransozo who made helpful comments on earlier drafts of the manuscript.

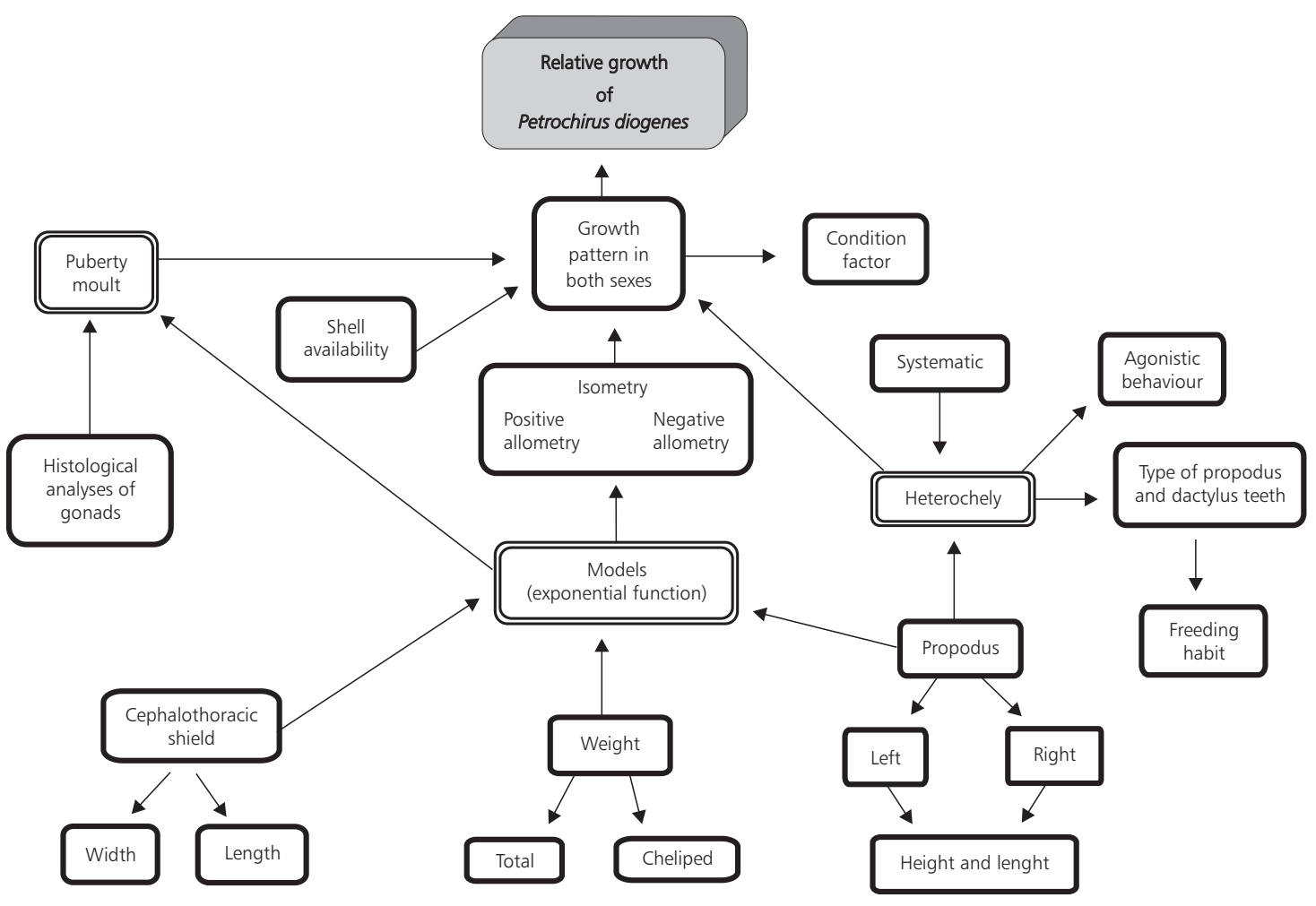

Fig. 7 - Fluxogram representing relative growth analyses in $P$. diogenes.

\section{REFERENCES}

ASAKURA, A., 1995, Sexual differences in life history and resource utilization by the hermit crab. Ecology, 76(7): 2295-2313.

BERTINI, G. \& FRANSOZO, A., in press, Population dynamics of Petrochirus diogenes (Linnaeus, 1758) (Crustacea, Anomura, Diogenidae) in the Ubatuba region (SP), Brazil. Crustacean Issues.

BERTNESS, M. D., 1981a., Pattern and plasticity in tropical hermit crab growth and reproduction. Am. Nat., 117: 754773.
BERTNESS, M. D., 1981b, The influence of shell-type on hermit crab growth rate and clutch size (Decapoda, Anomura). Crustaceana, 40: 197-205.

BERTNESS, M. D., 1981c, Interference, exploitation, and sexual components of competition in a tropical hermit crab assemblage. J. exp. mar. Biol. Ecol., 49: 189-202.

BLACKSTONE, N. W., 1985, The effects of shell size and shape on growth and form in the hermit crab Pagurus longicarpus. Biol. Bull. mar biol. Lab. Woods Hole, 168: 75-90.

BLACKSTONE, N. W., 1986, Variation of cheliped allometry in a hermit crab: The role of introduced periwinkle shells. Biol. Bull., 171: 379-390. 
CARLON, D. B. \& EBERSOLE, J. P., 1995, Life-history variation among three temperate hermit crabs: The importance of size in reproductive strategies. Biol. Bull., 188: 329-337.

CLAYTON, D. A., 1990, Crustacean allometric growth. A case for caution. Crustaceana, 58(3): 270-290.

DONALDSON, W. E., COONEY, R. T. \& HILSINGER, J. R., 1981, Growth, age and size at maturity of tanner crab Chionoecetes bairdii Rathbun, in the northern gulf of Alaska (Decapoda, Brachyura). Crustaceana, 40(3): 286302 .

DRAPKIN, E. I., 1963, Effect of Rapana bezoar Linne (Mollusca, Muricidae) on the Black Sea fauna. Doklady Academii Nauk SSR, 151: 964-966.

EMMERSON, W. D. \& ALEXANDER, M. D., 1986, Shell utilization and morphometrics of the hermit crab Diogenes brevirostris Stimpson. S. Afr. Tydskr. Dierk, 27: 211-216.

FOTHERINGHAM, N., 1976a, Effects of shells stress on the growth of hermit crabs. J. exp. mar. Biol. Ecol., 23: 299305 .

FOTHERINGHAM, N., 1976b, Population consequence of shell utilization by hermit crabs. Ecology, 57: 570-578.

FOREST, J. \& SAINT LAURENT, M. de, 1967, Campagne de la Calypso au large des côtes atlantiques de 1'Amérique du Sud (1961-1962). 6. Crustacés Décapodes: Pagurides. Ann. Inst. Oceanogr., 45(2): 47-169.

GHERARDI, F., 1991, Relative growth, populations structure, and shell utilizations of the hermit crab Clibanarius erythropus in the Mediterranean. Oebalia, 17: 181-196.

GHERARDI, F. \& MACLAUGHLIN, P. A., 1994, Shallowwater hermit crabs from Mauritius and Rodrigues Islands, with the description of a new species of Calcinus. Ruffles Bull. Zool., 42: 613-636.

GHERARDI, F. \& CASSIDI, P. M., 1995, Life history patterns of Discorsopagurus schmitti, a hermit crab inhabiting Polychaeta tubes. Biol. Bull., 188: 68-77.

HALEY, S. R., 1973, On the use on morphometric data as a guide to reproductive maturity in the ghost crab, Ocypode ceratophthalmus (Pallas) (Brachyura, Ocypodidae). Pac. Sci., 27(4): 350-362.
HARTNOLL, R. G., 1974, Variation in growth pattern between some secondary sexual characteres in crabs (Decapoda, Brachyura). Crustaceana, 27(2): 131-136.

HARTNOLL, R. G., 1982, Growth. pp. 11-196. In: D. E. Bliss (ed.), The biology of Crustacea, Embriology, Morphology and Genetics. Inc. 2o vol. Academic Press, New York.

HAZLETT, B. A., 1966, Social behaviour of the Paguridae and Diogenidae of Curaçao. Studies fauna Curaçao and other Carib. Islands, 23: 1-143.

HAZLETT, B. A. \& BOSSERT, W. H., 1965, A statistical analyses of the aggressive communication systems of some hermit crabs. Anim. Behav., 13: 357-373.

MANJÓN-CABEZA, M. E. \& GARCÍA RASO, J. E., 1995, Study of a population of Calcinus tubularis (Crustacea, Diogenidae) from a shallow Posidonia oceanica meadow. Cah. Biol. Mar., 36: 277-284.

MANTELATTO, F. L. M. \& FRANSOZO, A., 1992, Relação peso/largura da carapaça no caranguejo Hepatus pudibundus (Herbst, 1785) (Crustacea, Decapoda, Calappidae) na região de Ubatuba, SP, Brasil. Arq. Biol. Tecnol., 35(4): 719-724.

MARKHAM, J. C., 1968, Notes on growth patterns and shell utilization of the hermit crab Pagurus bernhardus (L.). Ophelia, 5: 189-205.

PINHEIRO, M. A. A. \& FRANSOZO, A., 1998, Sexual maturity of the speckled swimming crab Arenaeus cribrarius (Lamarck, 1818) (Decapoda, Brachyura, Portunidae), in the Ubatuba littoral, São Paulo State, Brazil. Crustaceana 71(4): 434-452.

PROVENZANO, A. J., 1968, The complete larval development of the west indian hermit crab Petrochirus diogenes (L.) (Decapoda, Diogenidae) reared in the laboratory. Bull. Mar. Sci., 18(1): 143-181.

REIGADA, A. L. D., NEGREIROS-FRANSOZO, M. L. \& MANTELATTO, F. L. M., 1994, Avaliação do tamanho dos quelípodos de Hepatus pudibundus (Herbst, 1785) (Crustacea, Calappidae), em relação ao sexo e à maturação. Arq. Biol. Tecnol., 37(4): 797-807. 